\title{
The propaganda offensive and the strategy of contact
}

The French army faced a major problem in its campaign of emancipation, how to reach out to the mass of over four million women, 98 per cent of whom were illiterate and scattered over the surface of a huge territory in villages or secluded settlements that were hours away by foot or donkey from the nearest roads. As we have seen (chapter 2) during 1957 Operation Pilot tested integrated methods of psychological action in the bled under the direction of itinerant propaganda officers, utilising tracts, slogans, loud-speaker lorries, mobile cinemas and other means of communication. This, and two further chapters, examine in more detail three key dimensions of the accelerating attempts at bridge-building, a 'strategy of contact': firstly, this chapter looks at the role of mass media communication (print, film and radio) which was developed centrally by the government and military to reach women across the entire geographical space of Algeria. This is followed by chapter 5 on the role of the MSF, local associations that operated mainly in the big cities and the smaller, European-dominated provincial towns; and chapter 7 on the mobile welfare teams (EMSI), which provided the main form of contact in the rural interior. This does not exhaust all of the multifarious ways in which the French attempted to transmit their ideas to the female population, but provides a fairly comprehensive picture of the overall strategies deployed by the colonial power. ${ }^{1}$ Three questions can be asked of this propaganda offensive: what techniques or methods were deployed to maximise communication? What does the content tell us about the ideological message and the underlying model of emancipation that was diffused? And, lastly, did the propaganda have any lasting effect on Algerian women?

By the outbreak of the Algerian War in 1954 the French military had a long established theory and practice of propaganda as a necessary component of modern warfare. The First World War (1914-18) and the Russian Revolution of 1917 had ushered in the age of 'total war' and the standard military perception that the outcome of international 
conflict rested as much on the civilian populations that sustained war economies (now subject to direct attack, bombing and demoralising propaganda), as on the strength of regular armies. The growth of new forms of mass media, particularly film and radio, greatly increased the ability of states to develop powerful forms of propaganda that aimed covertly to alter or manipulate mass attitudes, frequently through nonrational processes (use of symbols, manipulation of emotions and prejudice). ${ }^{2}$ The French state, like most western powers, had since the First World War established its own specialised organisations, mainly within the Ministry of Defence, to study, research and test methods of psychological warfare. ${ }^{3}$ The French army, in its bid to counter the FLN and to win the battle for the 'hearts and minds' of the indigenous population, was thus able to draw upon a well-established 'science' of communication theory. The adaptation of psychological warfare to the specific conditions of the Algerian theatre, in which the Fifth Bureau (1957-60) played a dominant role, drew upon or merged two major contemporary currents of thinking. On the one hand there existed a sophisticated body of academic communication research, pioneered and financed by the US military after 1945 , a field of psychological warfare that was linked to a multitude of social science programmes in social psychology, psephology, advertising, journalism, market research, behaviourism, radio and television studies and other related disciplines. ${ }^{4}$ Such research was of considerable interest to the Fifth Bureau since it held out the promise of refining techniques that would shape the attitudes of target groups (in this instance women) by identifying their social characteristics, and testing and refining various propaganda techniques through effects research, opinion surveys, questionnaires and statistical analysis.

The second influence sprang from the context of the Cold War. During the early 1950s the Korean War had given rise to a 'brain-washing' panic in the west that 'Oriental' communism had found the means to assert a total control over the human mind using Pavlovian techniques. ${ }^{5}$ Many French officers of the Fifth Bureau in Algeria had passed through the Vietcong retraining camps in 1954 and were impressed by such methods of psychological indoctrination. ${ }^{6}$ The 1950 s was an era in which behaviourist theories, which would today be viewed as crude or overly simplistic, held wide currency, and this translated into an acceptance among many propaganda specialists that it was certainly possible, using correct scientific techniques, to imprint upon, or transform, the mind-set of Algerian people so as to achieve a compliant psychology. ${ }^{7}$

The organisation of psychological warfare went through various complex changes in the course of the conflict, but the most important phase (with which this study is mainly concerned) corresponded with 
the period of domination by the powerful Fifth Bureau between its inception in early 1957 and its disbandment in February 1960. The Bureau consisted of a central body in the État-Major (HQ) of the 10th Army (10th Région Militaire) in Algiers, under the dual guidance of Colonel Lacheroy and Goussault, and later of Colonel Gardes, and which had three operational sections: Études, which studied doctrine and the key themes, aims and objectives, to be transmitted via action plans to the various army units; Action, which was concerned with media production, information and the methods of transmission (press, radio, film); and Relations nationales, which liaised with the national and international media. ${ }^{8}$ In August 1957 the Minister of the Interior, Bourgès-Maunory, a keen advocate of psychological warfare, ordered that Fifth Bureau officers be attached to each of the three Army corps (Oran, Algiers, Constantine), and within the corps down as far as the battalion or sector level. ${ }^{9}$ The tentacular Fifth Bureau came to constitute an extremely influential and quasi-autonomous 'parallel hierarchy' manned by the equivalent of Soviet political commissars, doctrinaire exponents of revolutionary warfare who infiltrated into every level of the armed forces.

While the governments in Paris and Algiers made the key decisions as to which propaganda campaigns were to be launched, in line with major political initiatives, the Fifth Bureau HQ undertook to research, develop and produce films, photographs, radio broadcasts, press releases and other media material, or to issue directives to the officers attached to the different levels of command on the style and manner of propaganda to be implemented at local level. To give just one example, the Fifth Bureau, influenced by behaviourist theory on conditioned reflexes and psychological imprinting, ascribed a particular importance to repetitive slogans which it tested on Algerians, since, it was claimed, 'the Muslim has different reactions from that of the European', according to age, background and other criteria. The key slogans were then relayed throughout the Fifth Bureau network to be used in leaflets, posters, banners and painted on road-side walls. ${ }^{10}$ Such psychological testing of propaganda even extended to culture-specific theories of colour symbolism: for example, it was believed that Islamic tradition associated green with positive attributes (peace, happiness), while yellow was rather disliked, and the voting ballots for the referendum of September 1958 were printed white for a 'Yes' to de Gaulle, and violet, 'the colour of death', for a 'No'. ${ }^{11}$

However, it would be a mistake to accept the claims to 'scientific' methodology and professionalism at face value. There is much evidence to show that the senior 'experts' of the Fifth Bureau, all males and with 
long careers as army officers, held extremely doctrinaire opinions about revolutionary warfare, 'Orientalist' and male Eurocentric views of Algerian women, and had, in many instances, a shallow and quite amateurish knowledge of propaganda theory and research. For example, the major school of psychological warfare at Arzew, which between October 1957 and September 1959 trained 7,172 officers, was directed by Lieutenant-Colonel Bruges, and later by Colonel de Maison Rouge, neither of whom had any expertise in psychological warfare and had to undertake a crash-course reading of Jung, Mao Tse-tung, Marx, Lenin, Chakotin and other 'classics'. ${ }^{12}$ Servier was highly scathing of the work of Bureau officers in the field which he likened to 'a mediocre publicity campaign mounted by amateurs full of good intentions', and few of the specialists that ran the Fifth Bureau could even speak Arabic or Berber and had to depend on interpreters. ${ }^{13}$

The task of developing forms of communication that could reach all Algerian women presented a formidable challenge. The 1954 census counted a total of 4,880,800 females, of which 83.65 per cent lived in rural areas, in most instances scattered over a huge landmass and located in isolated douars that were without electricity and road links. Yet it was particularly important to the army propaganda offensive that it reach into the bled since this contained not only the majority of women, but also the terrain in which the guerrilla forces of the ALN had their major support base. The overall level of female illiteracy was 98 per cent, and while attempts were made in the 1950s to rapidly expand basic education for girls, in 1954 only 10.7 per cent received any form of primary schooling. This meant that the army was faced with the problem of how to influence or persuade a female population that had an extremely low level of political education, no understanding of abstract western concepts (such as the meaning of 'democracy'), and were unable to read newspapers, posters and leaflets. Algerian women lived in an intensely oral and visual culture in which the main sources of daily information about the outside world derived primarily from the spoken word and rumour.

During 1960-61 the French government carried out a sophisticated survey, based on statistical analysis of a questionnaire, in an attempt to gauge the different channels through which Algerian women received political information, so that the army could more effectively use those methods of communication likely to reach the 'target' audience. The study, which was carried out by the Laboratoire des sciences humaines appliquées (LSHA) based in Algiers, although completed late in the war, provides an insight into mass media communication and Muslim women. The LSHA was established under the control of the Comité 
d'action scientifique de défense nationale (CASD) in Paris following an exploratory meeting of leading academics at the General Government in March 1960 under the chairmanship of General Guérin. ${ }^{14}$ Guérin noted that a key objective of the initiative was to 'better inform the population of the bled', and the LSHA that undertook this task, which was created in October 1960, employed a small staff of trained academic psychologists. Among various projects carried out into the 'penetration and effectiveness of information in the Muslim milieu' was a survey of Algerian women that was to be based on 1,500 questionnaires carried out by fifty EMSI interviewers across Algeria and which were synthesised in August 1961 in a report, Étude sur l'information en milieu musulmane féminine. ${ }^{15}$

The report indicated a number of methodological weaknesses in the collection of the data and its analysis that was indicative of the problems of 'psychological profiling' of the female population. Firstly, the LSHA was dependent on the assistance of fifty EMSI teams to provide thirty questionnaire returns each, but the welfare assistants were not necessarily very well equipped to carry out this task and only 1,016 forms, rather than the 1,500 questionnaires planned, were actually returned. Of these 198 could not be utilised, leaving 818 forms. But the statistical analysis for these 818 women aged fifteen to eighty-five years revealed a very high percentage of blanks or 'non-returns' (NR) in relation to specific questions: for example in reply to the question, 'Do you read the newspaper or have it read to you?', about a half ( 46.3 per cent) made no reply. The director, Lacavalerie, was much exercised by this problem, since the statistics could be greatly falsified, and initially he tried to separate out, but without success, those women who did not reply since they were ignorant, from those who refused because they were suspicious or hostile towards the French. The EMSI were asked to make a note as to whether they thought each woman was favourable towards France, indifferent, distrustful or hostile, and some 30 per cent were placed in the last two categories of 'distrustful' or 'hostile'. ${ }^{16}$ That about a third of women were negative or hostile towards the exercise is high, if we keep in mind that those questioned would have almost certainly been those in the 'pacified' zones who were best known to the EMSI and had volunteered to attend the women's circles regularly.

As will be seen later (chapter 6) there is a mass of evidence, from army reports and autobiographical accounts, of the extent to which enquiries by the French were met by an almost impenetrable wall of silence that became known as attentisme. For the Algerian population in general, the best form of self-defence when threatened from both sides, by the army and the FLN, was not to disclose one's personal 
position. But in addition, the silence of women was reinforced by deeply entrenched cultural values: it was held reprehensible for them to speak at all in the presence of strangers or males, and certainly not on 'political' issues that were a male preserve. Reticence was not necessarily only an expression of a colonial power relationship, of women who were terrified by the questions posed by an occupying force that often deployed extreme force or repressive violence: Hélène Vandevelde-Daillière, in a very similar opinion poll carried out in post-independence Algeria a decade later, found it very difficult to gain access to women, and when she did so was met with a high level of non-replies and of resistance. ${ }^{17}$ A third of rural women (30 per cent), Vandevelde-Daillière found, thought politics was not the business of women, and another 26 per cent that politics 'served no purpose'; only 11 per cent ever discussed politics with somebody they knew, 39 per cent never did so, while 50 per cent refused or failed to answer the question. ${ }^{18}$ The extraordinary difficulty faced by the French army in trying to assess the opinions of Algerian women thus arose from a complex of factors, including seclusion in the domestic space, male honour and sensitivity to any attempt to approach their wives and daughters, fear of the occupying forces, refusal to answer questions relating to the public sphere controlled by males, and a high level of ignorance arising from illiteracy and isolation from the outside universe of information, political events and current affairs.

Despite these difficulties, the 1961 investigators concluded that the data returned still provided useful information as to the general trends in media communication. Firstly, the survey confirmed that print sources, including newspapers, whether read directly by the literate or read by them to the illiterate, constituted a minor channel of information. Under 10 per cent of rural women in the sample received news in this way, as opposed to the two outstanding means by which information was diffused, the radio and oral communication through social networks. Some 42.4 per cent of rural women listened to the radio one or more times a week, while about a half preferred to exchange information through social converse. The intensely oral and aural nature of Algerian culture reflected both the high level of illiteracy, as well as the traditional forms of female associational life, based on women's networks, gatherings in the Turkish baths (hamam) or at various family-based social functions (weddings, circumcision, Aïd, local pilgrimages) in which local news, story telling and the exchange of information played a key role.

The report showed that reading of newspapers and listening to radio was frequently not an individual and private act, but a group activity. Newspapers, for example, which were relatively expensive, were 
Table 2: Social practices of listening to radio broadcasts (\%)

Where do you listen to the radio?

\begin{tabular}{lrcc}
\hline & Men & All women & Rural women \\
\cline { 2 - 4 } At home & 38.2 & 38.0 & 28.2 \\
At a neighbours or friends & 14.2 & 25.7 & 28.1 \\
Public or collective radio & 8.2 & 4.5 & 6.7 \\
No reply & 39.4 & 37.8 & 38.0 \\
\hline
\end{tabular}

Source: SHAT 1H2463, Étude sur l'information en milieu musulmane féminine (1961), Appendix K.

frequently read out aloud by those who were literate to a wider kin or social circle. This was also true of the radio as is shown in table 2 .

Since information was transmitted within a group setting, this meant that it was not simply received by each individual in an unmediated way, but was subjected to intense debate and evaluation by kin, neighbours and local leaders. As Daniel Lerner found in a not dissimilar situation in the Turkish village of Balgati in 1950, a wealthy and conservative headman who owned the only radio ceremoniously played the news to a select group and afterwards subjected it to a commentary. ${ }^{19}$ Since access to the media occurred within the ambit of the extended family or kin group, it would seem highly likely that information was both selected and shared upon the basis of pre-existing group loyalties. Michel Launay, as an anti-war conscript, went every Saturday evening to listen to the nationalist Voix de l'Algérie libre in the family of his friend Mazouzi. ${ }^{20}$ Fanon emphasised the collective nature and group mediation of listening to the radio, 'The old resistance to intra-familial contact disintegrated and one can see in a douar family groups of fathers, mothers and daughters elbow-to-elbow gazing at the face of the radio in the expectation of Voix de l'Algérie'. ${ }^{21}$ As the 1961 study concluded, what was more important than the 'raw data' of news items received by radio or newspapers, was the 'transformation' or interpretation of the information within the social circle. However, the majority of women showed little understanding of politics, of abstract concepts like 'democracy' or the significance of expressing their voice through the ballot box. The report found that in its present form information tended to be adapted to the needs of the minority of educated women, while its penetration among the mass of illiterate women was feeble, and among rural women preference was shown for radio transmissions of popular music and songs (55.2 per cent) than for news items (14.6 per cent). A decade later members of Vandevelde-Daillière's team found a similar 
situation, particularly in rural areas and shantytowns, where many women had absolutely no access to radio, newspapers or other sources, and responses in reply to questions ranged from, 'do not understand what is being said to them' to showed 'inertia and total indifference': 'For these women there is a total ignorance of the world outside the family, the world of public affairs'. ${ }^{22}$

However, the French army, as well as Franz Fanon and the FLN, were quite right to see radio as the most powerful instrument for reaching out to an illiterate audience that was isolated and scattered over a huge and difficult terrain. But before examining the content of the radio programmes that were specifically designed for women, we take a look at the propaganda use of film which provided another powerful, visual means for reaching an uneducated audience: as General Jacquier noted in November1960, 'The film is, along with the radio, the most effective means of communication that we have in our action upon the Muslim population'. ${ }^{23}$

\section{Film and photographic propaganda}

In the half-century before the outbreak of the Algerian War there had been a significant production of commercial, long métrages films shot on location in the Maghreb. Most popular were exotic Orientalist genre films located in the desert or Arab souks in which typically a European beauty, captured by a lascivious sheikh, was rescued by the French hero from a harem: cinema goers to Yasmina (1926), for example, were promised 'all the magic of the Orient, all the sensuous display of the harem, all the voluptuous lyricism of its captives, the precious flowers of an enchanted hot-house'. ${ }^{24}$ However, while this production is of interest for what it may tell us about the stereotypical perceptions of Algerian women that many French soldiers brought with them to North Africa, what I am concerned with here are the short documentary or news items filmed by the army for, or about, Muslim women during 1954-62.

The Service cinématographiques des armées (SCA), founded in August 1946, centralised both photographic and film production and diffusion for the Algerian armed forces from its HQ in the Martimprey barracks in central Algiers. ${ }^{25}$ The SCA included a team of professional army photographers and cameramen who were sent out daily to cover key events, such as the Forum demonstrations, or to cover particular propaganda themes, of which a favourite was the heroic medical work of EMSI teams in the bled and the 'modernisation' of Muslim women. Photographic film was rushed daily from the 'field' by plane, helicopter, van or train to the SCA laboratory for development and rapid diffusion to the various press 
agencies of the Ministry of Defence and the Fifth Bureau, and by daily plane to Paris for distribution to the national and international press agencies like Keystone and International. ${ }^{26}$ Documentary films, printed in multiple copies, were likewise distributed to French television and to commercial cinema companies or, internally within the army, in both French and Arab-language versions, via the Fifth Bureaux hierarchy to army units and mobile propaganda teams (CHPT).

The Fifth Bureau exercised a close control over the themes or subjects that were to be emphasised, including various aspects of women's emancipation, but also those topics to be avoided, such as 'the systematic destruction of douars or villages', heavy artillery and tank shelling, 'shantytowns, poverty-stricken quarters, houses in ruin', and 'slovenly, hirsute soldiers' ${ }^{27}$ A censorship committee exercised a control, not always with success, over the commercial films shown in Algerian cinemas, and among examples of those which raised concern was the Resistance film La Bataille du Rail (1945) in which railway workers sabotaged a Nazi troop train and which, after its projection in Bouira in November 1956, was thought to have triggered FLN attacks on the Algiers-Constantine line. ${ }^{28}$ Also banned was Hiroshima Mon Amour (1959), perhaps seen as creating opposition to the nuclear test programme in the Sahara, and the cowboy film L'Homme de San Carlos (USA: Walk the Proud Land, 1956) in which an Apache reservation moved away from submission to the US army towards peace and autonomy. ${ }^{29}$ Egyptian Arab-language films were of particular concern to the French since they conveyed the spirit of Arab nationalism and depicted a 'modern and prosperous country' to the disadvantage of colonial Algeria. ${ }^{30}$ Psychological warfare officers were concerned that Egypt might offer an image of modernity, particularly in the female sphere of domesticity, that demonstrated how the Arab state could reach levels of consumer prosperity well in advance of colonial France. One report noted how a film broadcast on television, 'gives an extremely flattering idea of the standard of living of Egyptians that one sees living "à l'américaine". Ultra-modern interiors, luxurious cars, etc. ... giving an impression obviously in contradiction with the real way of life of the Egyptian people'. ${ }^{31}$ By 1956 over 250 Egyptian films had been granted import licences for screening in the thousand cinemas across Algeria but, despite a blanket ban imposed in 1958, the army was unable to stop them reaching a wide popular audience. Egypt retaliated by producing Diamila Boubired, an account of the FLN terrorist bomber and heroine who was captured by the French, tortured and sentenced to execution. A further blow for anti-colonial film-making was struck when fifteen Algerian trainees at a French film school defected to Tunisia to work with the FLN. ${ }^{32}$ 
Once a week the head of the SCA, Captain Rouy, met in a briefing meeting with the head of the Fifth Bureau to agree on the appropriate themes to be covered by the SCA film unit, and during the course of 1957 attention turned increasingly to the making of documentaries that illustrated the emerging emancipation strategy and which could be shown to audiences of Algerian women to convince them of the benefits of 'modernisation'. For example, a SCA unit was sent in August 1957 to the heart of the Operation Pilot pacification programme in the Bou Maad area to photograph the new EMSI teams at work (see illustration 1, p. 96). The journalists described the primary purpose of the teams as 'the penetration of the Muslim feminine cell and child-care training', disclosing the primary intelligence function of the operation as much as its social welfare purpose. ${ }^{33}$

In July 1957 the SCA also produced a three-minute documentary, Nurses of the Bled, which showed the new mixed EMSI teams of young European and Algerian women at work, symbols of 'fraternisation', heroic self-sacrifice and medical progress. The opening scene of the film showed villagers living in squalor and hunger, and the narrator emphasised that these were the conditions faced by people living under the control of the FLN before the French army arrived to liberate them from terrorism and poverty: 'The young women of Algeria and the Metropolis have agreed to be "harnessed" to this tremendous task with courage and faith'. The EMSI was then shown departing every day on foot, by horse or army helicopter to the most isolated villages that could not be reached by road, and where the care for children and the sick established a new trust with the population. During subsequent visits to the same villages men, women and children were shown pressing round in greeting: 'Here, a warm and sympathetic friendship is created ... here the smiles of all the little children of Algeria who will keep for ever the memory of these young women from the Metropolis and Algeria, a symbol of French solidarity'. ${ }^{34}$ The months after the events of ' 13 May' 1958 was especially productive in documentaries about the process of unveiling, the general emancipation of Algerian women, and the campaign to persuade them to exercise their new right to vote in the September referendum and National Assembly elections of November. The SCA produced 500 prints of 'A Full French Citizen', 600 of 'Vote Yes', and a range of other titles that included 'How to Vote', 'The Arab Woman of the Bled', 'The Falling Veil', and 'Woman, Blessing of God'. ${ }^{35}$

The Algerian government was fully aware of the crucial importance of this photographic and film propaganda in the battle for international public opinion. The SCA was highly successful in its distribution of free images that were passed via major agencies in such a way 
that they carried credits such as Keystone or Agence France-Presse, so that their military source was concealed, 'to avoid giving the impression that information had been orchestrated'. ${ }^{36}$ The SCA was proud to claim that between 50 and 75 per cent of global press, TV and cinema images during the Algerian War, unknown to the public, originated with army journalists. A particularly prominent part of this propaganda was devoted to the EMSI, since images of blond young nurses bathing or inoculating Algerian babies while smiling and grateful peasant mothers looked on neatly encapsulated a multitude of messages: the peaceful nature of colonial rule, the enthusiastic acceptance of the Algerian populace, the love and self-sacrifice of the French, the warm inter-communal relations of both sides, liberation from backwardness and squalor, and the building of a new society (see illustration 1, p. 96).

The head of the SCA, Captain Rouy, pressed for the 1957 documentary Nurses of the Bled to be completed as quickly as possible so that it could reach commercial cinemas in metropolitan France and be dispatched to New York in time for a coming session of the UN which was about to debate the Algerian War. ${ }^{37}$ An important production and distribution role was played by the private company Tangent Films in ensuring that French propaganda films of the Algerian War, most of them illustrating the civilising process of 'pacification', reached a wide American audience. ${ }^{38}$ One of these productions, The Falling Veil (c. 1960), showed de Gaulle arousing Muslim women from their mental torpor, so that they were 'electrified' into liberating themselves from patriarchal oppression, and able to achieve progress towards modern civilisation that was illustrated, notes Matthew Connelly, by French women taking 'their Algerian counterparts in hand to hat shops and post offices, enacting practices of modernity for their protégés to mimic' ${ }^{39}$ This propaganda battle for American public opinion was to prove of crucial long-term importance since the eventual termination of the war, and the withdrawal of the French, came about as much through pressures exerted by international diplomacy, and in particular by the USA and the UN, as it did from FLN guerrilla warfare. ${ }^{40}$

How did films reach the domestic audience of Algerian women, and what kind of influence, if any, did they have? The colonial government had used the Ciné-bus from 1943 onwards to show official films in the more isolated regions of the colony, ${ }^{41}$ but such methods were greatly expanded during the course of the war. Films were distributed by the SCA to army units and the SAS/SAU, which had some 400 projectors, to show to local audiences in village halls, women's circles and other venues. In addition specialised propaganda units, the CHPT, copied in 1956 from American Loudspeaker and Leaflet Companies, began to 
deploy mobile cinemas, including a type of screen (cinéma jour) that could be viewed in the open air during daylight. ${ }^{42}$

SCA reports during 1957 show an increasing ambition to reach audiences of Algerian women, in line with the centrally directed campaign of emancipation. In December 1957 it noted that during the previous year Algerian attendance at army-mounted film shows had doubled and, 'among these spectators we can now count numerous Muslim women, a happy portent for the evolution of these women and for the whole of Algeria'. ${ }^{43}$ A tour by a Ciné-bus unit in the Department of Mostaganem in October 1957 had in ten shows attracted an audience of 19,150, of which 8,600 were Muslim women, and it was thought that women were being drawn in increasing numbers by films. ${ }^{44}$

There is little evidence as to the impact of such documentary films but relatively high attendances may have reflected the novelty and entertainment value for women who had, in many instances, never seen a film in their life. Certainly the army liked to use film-shows, frequently including Hollywood cartoons, as a means of drawing in a female audience that could then be subjected to speeches by EMSI and other women propagandists. Jean Servier and his commando associates cried with laughter at the seriousness of a captain seeking their advice on the advisability of showing an English-language version of Donald Duck to the villagers of Tifra in Kabylia: implying that the psychological warfare units revealed an absurd lack of understanding of the potential audience. ${ }^{45}$ But in general women, who watched films in segregated sessions with their children, seem to have been enthusiastic, even if, as the wife of an SAS officer noted, they understood nothing and reacted with nervous laughter to occasional romantic scenes and kissing. ${ }^{46}$ The soldiers who manned the CHPT rarely had any knowledge of Arab or Berber dialect, and were in little position to judge whether the messages were suited to the culture of the audience. Music that was played over loudspeakers from disks was sometimes more suited to a brothel, and Monique EocheDuval notes that, 'the words of the songs and the music was a little bit too suggestive in this land where the men would not listen to such things in the presence of their wives' ${ }^{47}$ General Crépin, in a directive which ordered the projection of a new SCA film, Femmes, throughout Algeria, remarked that it was difficult for such short documentaries to suit the tastes and the complexity of different types of audience that varied from one region to another, and in this instance, where 'the female rural milieu has only a very vague idea of the way of life in the town' ${ }^{48}$

Such evidence would seem to indicate that cinema propaganda was not so professionally produced to match the needs of respective female audiences as the Fifth Bureau often liked to claim. The overall impact 
on attitudes or political opinion may have been quite superficial, but in addition the FLN political cells (OPA) certainly encouraged people not to attend film shows or, in some instances, to actively disrupt proceedings. In 1957 one projection by a Ciné-bus was disrupted by youths, some of whom were arrested, and by the audience whistling, while in 1959 another screening was sabotaged by the cutting of electricity cables. It was reported from pro-FLN villages that no women would attend screenings, ${ }^{49}$ while Captain Montaner of the SAU of Clos-Salembier (Algiers) recorded during July 1958 that the cinema hall he had organised was stoned by turbulent youths. ${ }^{50}$ As always the effectiveness of propaganda has to be gauged against the local political background, and in most instances the allegiances of women were determined not by individual choice but by the political colouring and solidarity of the extended family, kin or village group to which they belonged.

\section{Radio: the 'battle of the airways'}

From the First World War down to the age of satellite TV, radio broadcasting represented the single most powerful instrument in the armoury of state propaganda. During war-time it had the advantage of diffusing messages very rapidly across a national space, penetrating across borders or globally to reach into the privacy of the home of an 'enemy' population. It was a source of information that governments found particularly difficult to control or police. During the inter-war period most advanced states established powerful, short-wave transmitters that could broadcast to global audiences: France, for example, established the Poste Colonial in 1931 which by 1938 was broadcasting in thirty languages. The full propaganda potential of radio was not lost on General de Gaulle whose political career as national leader of the French Resistance was founded on his famous appeal from London on 18 June 1940.

In 1959 Frantz Fanon published his famous essay, 'Here is the Voice of Algeria', in which he argued that radio, particularly in the form of the new, portable transistor, represented a revolutionary tool for the nationalist movement. ${ }^{51}$ Fanon argued that until the War of Independence Radio-Alger was a 'transmission belt for the colonial power' and was produced for a predominantly European settler audience, who owned some 95 per cent of all radio sets. ${ }^{52}$ This colonialist hegemony was, however, challenged increasingly by neighbouring Arab nationalist stations and in particular by the Voix des Arabes, transmitted from Nasser's Egypt, which supported the Algerian struggle from its very inception. ${ }^{53}$ But, for Fanon, the most dramatic and revolutionary 
potential of radio was realised during 1956 when the FLN was given a voice by Moroccan and Tunisian stations, notably the Tunis-based La Voix de l'Algérie arabe soeur, and finally in December with its own transmission, Radio de l'Algérie libre et combattante. For Fanon, the Algerian masses which had previously shunned Radio-Algers and radiolistening in general as a form of penetration of alien European culturalimperialism into the very heart of the Muslim family, now flocked to gain access to the radio as a source of information that shattered French propaganda and blanket control over the media, and also became in its own right an act of resistance. Immediately Algerians rushed to buy-up every new and second-hand radio they could lay their hands on and Algerians apprenticed to European radio-electricians began to open their own workshops. ${ }^{54}$

The French government was confronted with the difficult problem of responding to this threat to its previous tight censorship and control of news media. Historically, the growth of radio war propaganda had confronted modern states with a dilemma: attempts to capture or reach 'home' audiences was very much dependent on the mass ownership or availability of radio sets, but such a proliferation might also enable the public to tune-in to 'dangerous' overseas or clandestine air-waves. Despite the drawbacks, the Nazis had been so convinced of the enormous propaganda potential of radio that they encouraged the manufacture of millions of cheap, mass-produced sets, the Volksempfänger ('people's receiver') so that by late 1939 over 70 per cent of households owned one. ${ }^{55}$ The French army had experimented with radio propaganda in 1951 during the war in Vietnam but had abandoned the idea because of the paucity of receivers among the population, even among the Viet Minh elite. ${ }^{56}$ In Algeria the total number of officially registered sets increased by 41 per cent from 418,325 in May 1958 to 590,782 in late 1960, in part due to the rapid spread of the new transistor radios, and between a sixth and a third of Algerians may have owned a set by $1960 . .^{57}$

The French government was well-informed of the pro-FLN propaganda being transmitted across the borders, mainly through the Groupement des contrôles radioélectriques (GCR) located at Fort du Mont-Valérien in the Paris suburb of Suresnes and its Algerian listening posts. The GCR produced a daily Bulletin d'écoutes générales with transcriptions of key intercepts. ${ }^{58}$ One response to the growing volume of pro-FLN broadcasts was to engage in the technically difficult and expensive process of jamming, which seems to have only succeeded in part, ${ }^{59}$ and the FLN Voix de l'Algérie libre responded by constantly changing wave-length. ${ }^{60}$ The government also tried to restrict the sale of 


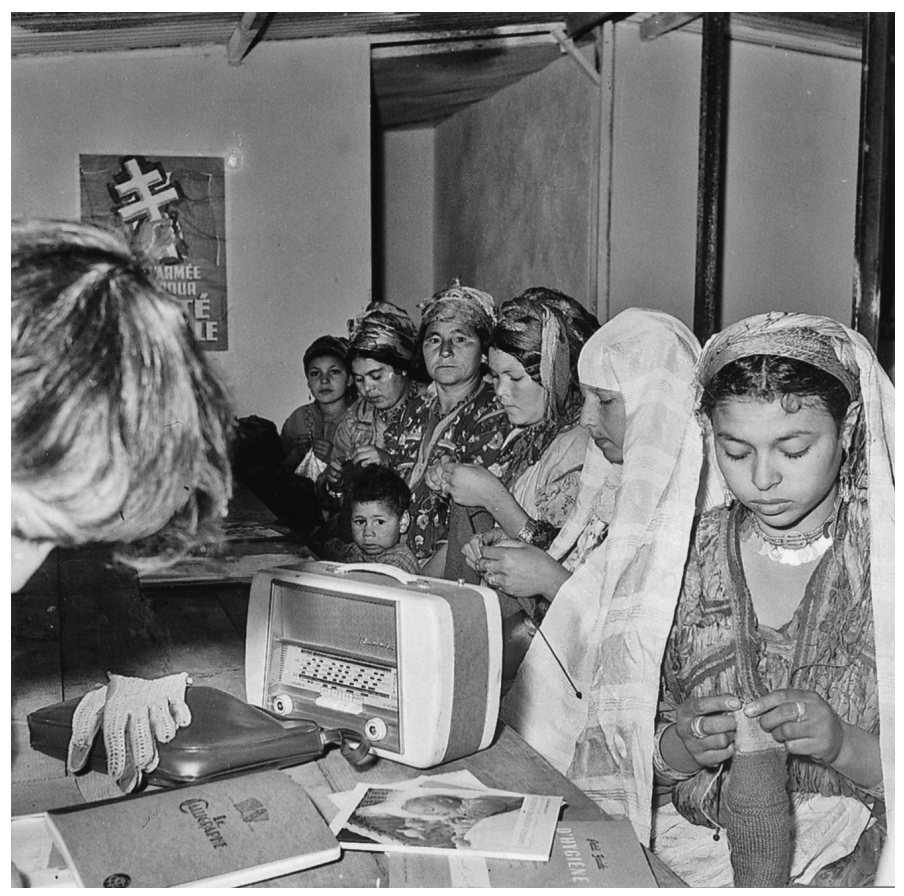

7 Women knitting and listening to the radio in the MSF circle of Palestro, January 1959

radios and batteries to Algerians by the decrees of 16 and 20 December 1957, particularly the light and portable transistor which was ideal for the isolated areas without electricity, while the army during its operations tried to seize or destroy as many sets as possible. ${ }^{61}$ But this only succeeded in creating a black market in radio equipment, including a cross-border trade organised by the maquis. ${ }^{62}$ The government seems to have recognised that it was impossible to prevent Algerian access to the radio, and moreover such a policy was counterproductive since it stopped people listening to official propaganda broadcasts. As the 1961 LSHA survey showed (see above), half of all women listened to the radio once or more a week, and this was regarded as by far the single most important source of information, particularly for the great mass of illiterate women in the bled. An alternative strategy considered by the Fifth Bureau, reminiscent of the German practice, was to mass produce a cheap standard radio that could then be widely installed in SAS, SAU, village halls, women's circles, youth clubs and other locations where group listening would be under the control of local officials, settlers and army officers. ${ }^{63}$ 
But the FLN OPA appears to have organised its own listening circles or group reception of nationalist transmissions and Zohra Drif, in her 1957 plan for a clandestine network of FLN women's cells in Algiers, included group discussion of the political situation based on listening to Radio-Tunis, Rabat or Radio Algérie Libre. ${ }^{64}$

The ethnologist Jean Servier appears to have been among the first to have commented on the considerable interest shown by Algerian women in listening to the radio, in particular the Kabyle-language broadcasts of Radio-Alger. ${ }^{65}$ In May 1957 General Noiret, commander of the Constantine region, undoubtedly aware of the newly emerging agenda on women, forwarded a report of the local Renseignements généraux (RG) which commented on the great popularity of Paris Arab-language broadcasts, particularly 'the latest songs', 'listener's letters', cultural programmes and 'those that relate to the life of Muslim women, the emancipation of the Arab woman and the evolution of customs'. A radio 'referendum' on the wearing of the face veil (hadjar) had aroused much interest among young women, 'among whom the desire for emancipation is very great and who begin to speak of equality of attitudes'. The RG's view was that much attention should be given to the organisation of radio transmissions to women: 'Besides the fact that these broadcasts could turn young Arabs away from listening to xenophobic and racist Arab radio, they are of a nature to accelerate the evolution of the Muslim woman and via her of Arab society as a whole towards previously unknown forms of liberalism'. ${ }^{66}$ This current of thinking was followed up during the summer of 1957 by Radio-Alger in its Arab and Kabyle versions of the Magazine de la femme, which welcomed a listener's debate on the veil and emancipation through its popular speaker, called 'Nadira'. But it was above all the events of ' 13 May' that was to give an enormous boost to radio propaganda, a key component of the wider campaign of emancipation that was accelerated throughout Algeria.

The remaining section of this chapter looks at the content of a particularly important weekly programme, the Magazine social de la femme, ${ }^{67}$ which was broadcast by Radio-Alger from early August to December 1958 in league with the newly formed MSF led by Lucienne Salan and Suzanne Massu. ${ }^{68}$ One of the first acts of the army conspirators on 13 May was to seize the building of Radio-Alger, an almost standard move in any modern coup. On the 17 May, the day on which veils were burned in the Forum, Massu, inspired by the heady atmosphere of 'fraternisation', claims to have gone on the spur of the moment into the radio station where she used her rank to demand of the parachutist guard an immediate access to the studios to make a spontaneous radio 
appeal. In the transmission she called on all women to come to her aid to ensure that the joyful flame of love and reconciliation demonstrated in the Forum should be nurtured by a nation-wide women's movement, 'This, my sisters, is our affair. Help me, come to me: this is Suzanne Massu in Algiers and I appeal to your assistance'. ${ }^{69}$

This appeal gave rise to the creation of the MSF, which will be examined in the following chapter, but what can be noted here is the considerable potential of radio to the emancipation movement, and this was soon to be translated into the regular broadcasts of the Magazine social de la femme. The Magazine, a fifteen-minute programme broadcast every Thursday and Sunday morning at $7.15 \mathrm{am}$ in French, and repeated the same day at $6.60 \mathrm{pm}$ in demotic Arabic, ran for eighteen weeks until its closure on the recall of General Salan and his wife to France in December 1958. After several weeks the programme began to assume a regular format which consisted of five elements, a four minute editorial presented by leading members of the MSF, medical advice (billet de docteur), brief news items mainly relating to charitable activities of the MSF, letters from listeners, and, most interesting of all, a popular address to Algerian women by 'Lalla Safiya'.

Mme Salan, as a highly active president of the MSF, exercised a tight control over the programme and it was she and her advisers in the General Government who decided on the theme of each week's editorial and approached the wives of leading generals, officers or functionaries to speak to these topics. Among those who participated in the editorials were, in addition to Salan herself, the wives of Generals Massu, Réthoré, Saint-Hillier and Jouhaud, Mme Goussault (wife of the head of the Fifth Bureau), and Mme de Marie, wife of the head of Salan's cabinet. Suzanne Massu, for example, on 11 August under the title 'Croisade de l'amitié spoke of the inter-faith solidarity of Christian, Muslim and Jewish women who were able to meet now in the women's circles of the MSF, 'activities include meetings of friendship, country picnics, group walks, seaside excursions, infant nurseries', where in spite of language differences they could speak 'the eternal language of women'. In contrast to the world of men, of politics and conflict, 'our weapon is the sewing machine'.

Other editorials addressed social issues, such as high unemployment, poor housing, the cess-pit anarchy of the bidonvilles, and solutions that promised to improve the quality of life for Algerian women, such as vocational training, the work of the Centres sociaux, schooling for girls, and new building programmes, solutions that were 'revolutionary and effective'. However, the key issues that were repeatedly addressed throughout 1958 related to the government campaign on the two most 
important planks in the emancipation movement: firstly, to persuade Muslim women to exercise their right to vote for the very first time in the referendum of 28 September and the legislative elections of November 1958 , and secondly, to persuade women of the fundamental importance of a reform of the personal status law. These issues are examined more closely in chapter 8 , but briefly it can be noted how the dominant radio discourse was one that emphasised the necessary struggle by Algerian women to escape from a medieval and oppressive past. Mme Goussault, in her editorial on 'Algeria in 1830', re-iterated a standard discourse used by colonial ideologues to legitimate both the conquest of Algeria, and the need for an enduring French presence. Goussault dwelt on the misery and backwardness of Algeria before the arrival of the French, the bloody tribal conflicts, cruel Turkish despotism, crushing taxes, piracy, general filth, lack of any hospitals and other 'odious abuses' that only France was able to abolish. Under the beneficent hand of France Algerian women could now emerge into the full light of modernity, an era marked by a high standard of living, good housing, clothing, food and health care for themselves and their children, self-fulfilment through education and leisure, and full economic and political equality with European women. Such a bountiful future could only be achieved under the governance of France and the almost superhuman and all-loving father figure, de Gaulle. As Mme Salan claimed in another editorial, only by voting 'Yes' for de Gaulle could a 'pacific revolution' be achieved: 'What a radiant future is promised for an Algeria that finds itself integrated and united with the Motherland, benefiting from the economic riches, the cultural treasures and techniques that are the fruit and inheritance preciously accumulated by France through the centuries'. To abstain from voting was to 'betray the Fatherland that has cherished you, it is to prepare the victory of the separatists and of international Communism'.

Other programmes approached the well-worn theme of unveiling, which was then linked by speakers to other issues of personal rights, polygamy, forced marriage and repudiation. Particular importance was attached to re-assuring Muslim women that reform of the personal status law, or exercising the vote, was not against their religion, but had already been addressed by other Islamic states, including Turkey under Mustapha Kemal, Egypt, Syria, Lebanon, and more recently Tunisia and Morocco. Frequent mention was made of the speech of the eminent religious leader Sheikh Lakhdari in Constantine on 26 May 1958 (see chapter 3). Princess Lalla Aïcha of Morocco and the 'beautiful Soraya', wife of the Shah of Persia, were held up as examples of royal women who had adopted reform, and Algerian women were encouraged to demonstrate that they too could be proud to embrace modernity. It was 
frequently suggested, in a discourse that must have sounded surreal to Algerian women living in shantytown slums, army resettlement camps and isolated douars without roads, running water or electricity, that they too could aspire to become the equal of their French sisters who historically had also to fight to achieve their rights and now enjoyed equality with men, able to, 'to go out, to engage in sport, to follow university courses, to become doctors, pharmacists, lawyers, or directors of industrial or commercial enterprises'. The radio, as did the MSF women's weekly magazine Femmes nouvelles, held up powerful role models of modernity, from champion rock-climbers and swimmers, to atomic scientists, film stars and princesses. ${ }^{70}$ A series of Arab-language broadcasts, Voter Oui, c'est assurer l'emancipation de la femme musulmane, informed Algerian women that their vote placed them on the same level as, 'a great scholar, a great writer or a great engineer. Such as Jacqueline Auriol, the fastest woman pilot in the world'. ${ }^{71}$ The French propagandists, unwittingly or not, were here following very much in the footsteps of an earlier tradition of middle-class Arab feminism and nationalism, particularly in Egypt, which centred on the life narratives of exemplary 'famous women', including non-Muslim subjects like Joan of Arc, Catherine the Great of Russia, Queen Victoria, George Sand and the American astronomer Maria Mitchell. ${ }^{72}$

Possibly the most effective part of the Magazine was the regular broadcast by 'Lalla Safiya', who presented herself as a simple and uneducated woman of the people who shared the tribulations and concerns of her 'sister' Algerians: 'I', she claimed, 'I am only a poor, ignorant woman'. In contrast to the more formal style of the editorials by elite European women, which were intended as much for a settler as an Algerian audience, this supposed mother of six addressed herself to illiterate Muslim women in a close personal and even affectionate way and larded her talks with popular aphorisms or religious epithets (Inch' Allah!). However, 'Lalla Safiya' was certainly a fiction and radio actresses played her role reading from scripts that were prepared by psychological warfare specialists. ${ }^{73}$ Such concealment was a standard tool of propagandists since revelation of the true identity of the organisation lying behind the message would create an immediate disbelief or doubt in the audience.

'Lalla Safiya' developed themes identical to those of the editorials (the role of education, the importance of the vote, reform of the personal status law, unveiling), but her message was packaged in a simple, but more subtle and user-friendly format. The style of the populist broadcast can be illustrated by that of 14 September 1958 on the theme of 'progress' in which Lalla argued against religious conservatism. 
Addressing herself to her 'dear sisters', she remarked that some of you will ask what is the point, 'All is in the hand of God!': to such religious fatalism she replied that we also are religious, respect our ancestors and visit their tombs, 'We also, we obey Islam . . . But Islam is a religion that is worth the effort: - The Proverb says: "Fasten your camel, and have trust in God"'. How can we possibly turn the clock back and live like our ancestors, she asked: 'In order to do that would we, the women, not have to destroy the mechanical mills and bring the hand mill back into every house? - Do we have to smash the water pipes and the fountains to go, as we did in the past, to fetch water at the spring? Do we have to burn down the hospitals and schools?'.

Lalla claimed to be won over to change by the example of her young and progressive (but fictitious) daughter. At one time Lalla had been backward and tried to stop her going to school, but she was now happy and enthusiastic to encourage her daughter: so listeners should do likewise with their sons and daughters and they would be richly rewarded, 'Inch' Allah!'. In a broadcast on the veil (21 September) Lalla again used her daughter as a foil, a symbol of progress, and noted that she herself has not worn a veil for two years since, "When I saw my daughter so happy to go out without a veil, I wanted to do like her'. Much of her advice was couched in a sensible, pragmatic and nondoctrinaire way: thus it was impossible to lead an active life dressed in the haik: 'To come and go in the town, to cross the road in the middle of the automobiles, to see well, to hear, to carry a parcel, you must, I can assure you, be dressed like a French woman. The habit is quickly learned!'. Women of the Aurès or Sahara had never worn the veil, but did that make them any the less Muslims? And how were they to manage veiled, 'to go and fetch water at the spring or well?'. In other programmes 'Lalla Safiya' reported her arguments with her fictitious grandmother, who initially refused to vote, or her conservative friend Malika who claimed that according to the Koran men were superior to women whose role it was to obey and remain within the home. Lalla, through kindly argument, won both of them over to her side: women should not 'remain like an animal that men can sell or buy ... like an old, blind horse that has to work the water-wheel', and the Prophet had declared, 'All the faithful are brothers'. In a programme on 30 November, a few weeks before the Magazine de la femme was closed down, Lalla announced that she was off to join an SAS in the interior as a social worker dedicated to the welfare of mothers and children. So 'dear friends of the bled' might in the future be able to recognise Lalla by her 'sympathetic voice' as she moved anonymously among them, no fiction but a living reality. 
The 'Lalla Safiya' broadcast, with its use of simple characterisation, its direct appeal to ordinary Algerian women through the voice of a warm and personable 'sister', shows how the army was able to invent more plausible and possibly successful propaganda. As the LSHA survey of 1961 indicated, at least half of all Muslim women listened to the radio one or more times a week, so a considerable number were likely to have listened to the Magazine or similar French propaganda transmissions. Today, even under the most sophisticated laboratory conditions, it is notoriously difficult to measure the impact of the mass media in changing basic attitudes or opinions, and the effectiveness of French propaganda cannot be conclusively assessed. Frantz Fanon, through what David Macey has called his 'revolutionary romanticism', entertained an exaggerated radical optimism as to the potential of pro-independence radio to forge a new Algerian national and political consciousness: but the overall impact of French army propaganda was probably even less than that of the FLN. It should be kept in mind that listening to the radio was frequently a group or quasi-public process that was mediated by other women, kin and villagers and where there existed support for the FLN, or deep hostility to the occupying armed forces, French propaganda would have been either subjected to withering criticism, switched off or re-tuned to nationalist wavelengths. Algerian women listening at home were also highly selective as to what they chose to hear, and French research showed that the majority of women (59.3 per cent) preferred to listen to music and songs, rather than to news or current affairs (18.6 per cent).$^{74}$ It seems unlikely that French radio broadcasts had any transformative effect on the emancipation of Algerian women, although the spread of the transistor radio into the isolated villages of the interior, in the absence of other means of mass communication, undoubtedly provided them with an important window on the rapidly changing events of the War of Independence.

\section{Notes}

1 In particular this study does not examine in detail the French policy of expanding educational opportunities for Algerian girls, especially at primary level, a long-term strategy that would only begin to change or affect women's attitudes well after the War of Independence was over.

2 For an overview see Garth S. Jowett and Victoria O'Donnell (eds), Propaganda and Persuasion [1986] (London: Sage Publications, 3rd edn 1999).

3 For a detailed history see Villatoux and Villatoux, La République, Parts 1 and 2. 
4 Simpson, Science of Coercion.

5 Susan L. Carruther, “Not Just Washed, But Dry-Cleaned”: Korea and the "Brainwashing" Scare of the 1950s', in Gary D. Rawnsley (ed.) Cold-War Propaganda in the 1950s (Basingstoke: Macmillan, 1999), 47-66; see also above, chapter 3, the influence of the Soviet Serge Chakotin.

6 Sylvie Thénault, 'D’Indochine en Algérie: la rééducation des prisonniers dans les camps de détention', in Brocheux et al. (eds), La Guerre d'Algérie au miroir, 235-49.

7 An overview of theory can be found in two seminars by M. Bonnemaison, a specialist in social psychology, Fondement de la guerre psychologique ( 7 November 1957) organised by the Fifth Bureau in Algiers in which he distinguished the 'American school' of 'mass-man' characterised by Carl Jung (the unconscious, archetypes, the image), and the 'Soviet school' based on Pavlov (instincts, conditioned reflexes): SHAT $1 \mathrm{H} 2409$.

8 Villatoux and Villatoux, 'Le 5e Bureau en Algérie', 409.

9 SHAT 1H2409, Instruction of Bourgès-Maunory [probably August 1957]. The French army in Algeria, which constituted the 10th Military Region, was subdivided under the central command in Algiers into three army corps (Algiers, Oran and Constantine), and each corps into zones corresponding to the twelve departments (fifteen after March 1958) and held by a division. The zone was further subdivided into sectors corresponding to an arrondissement and held by a regiment, and each sector was further sub-divided into quartiers: see Guy Pervillé, Atlas de la guerre d'Algérie (Paris: Éditions Autrement, 2003), 31.

10 SHAT 1H2409, L’Arme psychologique en 10e Région Militaire, August 1957.

11 SHAT 1H2409, Contrôle et sondage des resultants de la propagande à destination des musulmanes et rebelles, 23 February 1957; Monique EocheDuval, Madame SAS, femme d'officier. Algérie 1957-1962 (Paris: F.-X. de Guibert, 2007), 89.

12 Villetoux and Villetoux, La République, 445-6.

13 Ibid., 489, 486.

14 SHAT 1H2463, minutes of foundation meetings of LSHA, Algiers 23-24 March 1960. Among those present were Professors Marçais, Yacono and Malméjac, and Hadj Sadock of the Lycée of El-Biar.

15 SHAT 1H2463, Étude sur l'information en milieu musulmane féminine, 4 August 1961, 33, by Chef de Bataillon Lacavalerie, director of the LSHA.

16 The returns also showed a bias towards the European-dominated Oran region, where the EMSI were most present; also towards urban rather than rural women, and those who were better educated. The percentage of returns for illiterate (76.8 per cent) was well below the expected norm of 96-8 per cent.

17 Hélène Vandevelde-Daillière, Femmes algériennes à travers la condition feminine dans le Constantinois depuis l'indépendance (Algiers: Office des 
Publications Universitaires, 1980), 94-8, 228-65. The survey was carried out between February 1969 and February 1970, using a team of female students.

18 Ibid., 241, 263.

19 Daniel Lerner, The Passing of Traditional Society. Modernizing the Middle East [1958] (New York: Free Press of Glencoe, 1964 edn), 27.

20 Launay, Paysans algériens, 255.

21 Fanon, $L^{\prime} A n V, 67$.

22 Vandevelde-Daillière, Femmes algériennes, 229.

23 SHAT $1 \mathrm{H} 2515$.

24 Cited in Pierre Boulanger, Le Cinema colonial (Paris: Éditions Seghors, 1975), 62. On Orientalism and colonial film production in Algeria and the Maghreb see, in addition to Boulanger, Abdelghani Megherbi, Les Algériens au miroir du cinéma colonial: contribution à une sociologie de la décolonisation (Algiers: SNED, 1982); Richard Abel, French Cinema. The First Wave, 1915-1929 (Princeton: Princeton University Press, 1984), 151-60; Matthew Bernstein and Gaylin Studler (eds), Visions of the East. Orientalism in Film (London: I. B. Tauris, 1997); Ella Shohat and Robert Stam, Unthinking Eurocentrism. Multiculturalism and the Media (London: Routledge, 1994); David H. Slavin, Colonial Cinema and Imperial France, 1919-1939: White Blind Spots, Male Fantasies, Settler Myths (Baltimore: John Hopkins University Press, 2001).

25 Benjamin Stora and Marie Chominot, 'Photographes sous l'uniforme: regard croisés sur la guerre d'Algérie', in Laurent Gervereau and Benjamin Stora (eds), Photographier la guerre d'Algérie (Paris: Éditions Marval, 2004), 39-41. The SCA succeeded from the older Section photographique et cinématographie des armées founded during the First World War. The rich deposit of films and photographs can be consulted in the Établissement de communication et de production audiovisuelle de la Défense (ECPAD) at Fort d'Ivry, Paris. I have been unable to consult the recent thesis of Marie Chominot, Guerre d'indépendance de l'Algérie, l'image, source et objet de recherche historique, May 2008, Paris VIII: see also her unpublished research paper, 'Armée et photographie en guerre d'Algérie', Institut d'Histoire du Temps Présent (IHTP), Paris, 2 March 2004.

26 SHAT $1 \mathrm{H} 2515$ contains a wealth of information on the operations of the SCA.

27 SHAT 1H2515, directive 10 RM, 15 April 1957. A useful comparison with French film censorship and cinema in colonial Syria and Lebanon can be found in Thompson, Colonial Citizens, 197-210.

28 SHAT $1 \mathrm{H} 2409$.

29 SHAT $1 \mathrm{H} 2515$.

30 On French control and censorship of cinema and films in Algeria, especially Egyptian productions, see Sébastien Denis, 'Cinéma et panarabisme en Algérie entre 1945 et 1962', Guerres Mondiales et Conflits Contemporains, 226 (2007), 37-51. 
31 Ibid., 49, intelligence note 20 February 1957. The 6,000 TV sets in the Algiers area reached an audience of about 25,000.

32 SHAT 1H2515, General Challe note, 15 March 1960; Boulanger, Cinéma colonial, 8, 272; Connelly, Diplomatic Revolution, 28-9.

33 ECPAD - ALG 57/392, twenty-eight photographs taken 16 August 1957.

34 SHAT 1H2515, note of Captain Rouy, head of SCA, 6 July 1957, with analysis of film sequence and script. ECPAD was unable to locate for viewing any of the films relating to emancipation and Algerian women. Diane Sambron, Femmes musulmanes, 104, note 120, remarks that many of these films have been deposited at Aix with CAOM, archives du ministère de la Culture/films cinématographiques, but they cannot be viewed because of their poor condition. Connelly, Diplomatic Revolution, 216-17, was able to view some of these films and makes interesting comment on their content.

35 SHAT 1H2515, SCA, Réalisation de films de propaganda pour le référendum, 15 September 1958; Sambron 'La Politique', in Jauffret (ed.), Des hommes, 238.

36 SHAT 1H2515, SCA fiche, 15 September 1958. Paris Match, 476 (24 May 1958), showed several photographs of the unveiling ceremonies at the Forum on 17-18 May taken by its own photo-journalists Joël Le Tac and Daniel Camus under the rubric, 'The events of Algiers in photo, as seen by our special correspondents'. But two of the photographs of veil burning credited to Le Tac and Camus were taken by SCA photographers.

37 SHAT 1H2515, note of Captain Rouy, 6 July 1957.

38 Pacal Pinoteau, 'Propagande cinématographique et décolonisation. L'Exemple française (1949-1958)', Vingtième Siècle. Revue d'Histoire, 80 (2003/4), 55-69.

39 Connelly, Diplomatic Revolution, 216. The Falling Veil, Tangent films, London, c. 1960, was directed by Robert W. Schofield. Schofield had links with the French producer J. K. Raymond-Millet, who specialised in making propaganda films in colonial North Africa between 1929 and 1955.

40 The FLN was clearly aware of the importance of emancipation to French international propaganda: one captured internal document commented on the 'publicity aims: the newspapers, the films, and declarations enable the world to be informed of the so-called "humane task" undertaken by France for the Algerian people', SHAT 1H2461/1, report captured 26 November 1958 on the corpse of Si Boumédienne.

41 Boulanger, Cinéma colonial, 271; Villatoux and Villatoux, La République, 382.

42 SHAT 1H2515, SCA note on cinéma jour project, 17 October 1957. A photograph (ECPAD ALG57 83 R06) shows such a cinema in operation.

43 SHAT 1H2515, Le Role du Service de Diffusion Cinématographique depuis la naissance d'une Arme Nouvelle. L'Arme psychologique, by Plassard, Chef Adjoint, 5 December 1957. Underlined as in the original text.

44 SHAT 1H2516, report of Murati, head of the Service de Diffusion Cinématographique (SDC), 9 November 1957. 
45 Servier, Adieu Djebels, 49-51.

46 Eoche-Duval, Madame SAS, 57-8.

47 Ibid., 190.

48 SHAT 1H2515, Crépin directive, 3 May 1960.

49 SHAT $1 \mathrm{H} 2516$, reports of SDC.

50 CAOM 2SAS59, monthly report for SAU Clos-Salembier, July 1958.

51 Fanon, L'An V, 51-82.

52 Ibid., 51, 77; see also Macey, Frantz Fanon, 328-30.

53 Charles-Robert Ageron, 'Un aspect de la guerre d'Algérie: la propaganda radiophonique du FLN et des États arabes', in C.-R. Ageron (ed.), La Guerre d'Algérie et les Algériens, 1954-1962 (Paris: Armand Colin, 1997), 245-6.

54 Fanon, L'An V, 66-7.

55 David Welch, The Third Reich: Politics and Propaganda (London: Routledge, 1993), 30-4.

56 Villatoux and Villatoux, La République, 253.

57 Ferro (ed.), Le 13 Mai 1958, 16; Ageron, 'Un aspect', 249.

58 CAOM 15CAB118, 'La Propagande radiophonique de la rebellion', 10 March 1961; copies of the daily bulletins are in CAOM $81 \mathrm{~F} 367$ and $81 \mathrm{~F} 888$.

59 SHAT 1H2516, reports on jamming (brouillages), include a note of 8 June 1961 that jamming of medium waves was failing to 'counter effectively an aggressive propaganda'; CAOM 15CAB118, 'La Propagande radiophonique', reports that jamming of medium waves was more effective than short wave transmissions, and for towns than for rural or frontier areas.

60 Fanon, L'An V, 69, 72.

61 Launay, Paysans algériens, 315, notes that by 1960 the transistor radio had become almost a necessity of the peasant household. The main impediment to their regular use was the cost of batteries.

62 Fanon, L'An V, 68-9.

63 SHAT 1H2409, Réunion du Comité Mixte d'Action Psychologique, 4 October 1957; Welch, Third Reich, 30-4, notes that the mass produced 'people's receivers' had a limited range so foreign broadcasts could not be listened too; community listening, or broadcasts by loudspeakers in public spaces and factories, also ensured a sense of national belonging and conformity.

64 SHAT 1H2582, 2e Bureau, Organisation féminine de la Z. A. Alger, 14 October 1957.

65 CAOM 13CAB7, report from Tizi-Ouzou, 12 August 1956.

66 SHAT 1H2461/1, note of R. G. Constantine, 7 May 1957.

67 While unclear from the archive sources it is likely that Magazine social de la femme was a re-named version of the older women's programme Magazine de la femme.

68 The full script for most of these broadcasts, in CAOM 13CAB61, provide an invaluable source for the propaganda content of radio programmes directed towards Algerian women. 
69 Massu, Le Torrent, 99-101; CAOM 13CAB61, Mme Massu, Message aux amies de toutes confessions [n.d].

70 Femmes nouvelles, 20 February 1959, special issue on 'The Empress and Simple Citizen: SORAYA', and 6 March 1959, with numerous photographs of female mountaineers and swimmers.

71 SHAT 1H11471/1, Operation Referendum, transcripts of twenty-eight RTF programmes, August-September 1958.

72 Marilyn Booth, 'The Egyptian Lives of Jeanne d'Arc', in Lila Abu-Lughod (ed.), Remaking Women. Feminism and Modernity in the Middle East (Princeton, N.J.: Princeton University Press, 1998), 172; and "“May Her Likes Be Multiplied": "Famous Women” Biography and Gendered Prescription in Egypt, 1892-1935', Signs, 22: 4 (1997), 827-90.

73 The internal evidence of a fictional character can be found in the bizarre contradictions in 'Lalla's' biography, detailed technical annotations to the scripts and other features.

74 SHAT 1H2463, Étude sur l'information en milieu musulman féminine, 4 August 1961. 